\title{
Domestic Crony Capitalism and International Fickle Capital: Is There a Connection?*
}

\author{
Shang-Jin Wei \\ Brookings Institution, Harvard University, NBER and CEPR.
}

\begin{abstract}
Domestic crony capitalism and fickle international capital flows are often suggested as two rival explanations for currency crises. This article examines a possible linkage between the two that has not been explored much in the literature: domestic crony capitalism may make a country more dependent on the more fickle type of international capital flows (e.g. international bank loans) rather than the less volatile type (e.g. foreign direct investment). It presents statistical evidence that the degree of domestic crony capitalism is indeed associated with a higher external loanto-FDI ratio. Such a composition of capital flows has been identified as being associated with a higher incidence of a currency crisis. Therefore, even though crony capitalism does not forecast the exact timing of a crisis, it can nevertheless increase its likelihood.
\end{abstract}

\footnotetext{
* This research project is supported in part by a grant from the OECD Development Centre. I thank Marty Feldstein, Jeff Frankel, Helmut Reisen, Dani Rodrik, Andrei Shleifer, Benn Steil, and two referees for very helpful discussion, Rafael di Tella, Ernesto Stein and Ugo Panizza for sharing their data, and Rachel Rubinfeld, Mike Prosser, and particularly Yi Wu for superb research and editorial assistance.
} 


\section{Introduction}

Crony capitalism is an economic system in which the adjudication of commercial disputes as well as the allocation of resources are generally made to favour those who have a close relationship with political leaders or government officials (by blood or by bribes). It is a system in which connection trumps competence, and money supersedes merit.

Fickle international capital refers to the fact that the international capital flows can be highly volatile. Capital flows to developing countries, in particular, are said to be subject to sentiment shifts by international investors, overreaction to minor changes in the fundamentals, momentum trading, herding, or contagion. ${ }^{1}$ Some of the terms in the last half sentence are not always well defined. ${ }^{2}$ However, one can say that not all types of capital flows are equally volatile. For example, between 1980 and 1996, international bank loans were 2-4 times as volatile as international direct investment. ${ }^{3}$

Both crony capitalism and fickle international capital have been proposed independently as plausible explanations for currency crisis in developing countries. The role of crony capitalism in the recent Asian crisis as a trigger or a contributing factor has often been alleged in journalistic reports. However, there is a lack of direct statistical evidence supporting this hypothesis, with the notable exception of Johnson et al. (2000) and Wei and Wu (2001b). ${ }^{4}$ One reason for the relatively small size of the empirical literature is that the degree of crony capitalism is hard to quantify. The other reason is its apparent failure to forecast the timing of a crisis. It is not difficult to find examples of countries experiencing a currency crisis also having a severe corruption problem (e.g. Thailand and Indonesia). However, it is not easy to find examples of countries whose corruption problem had turned dramatically worse just before a currency crisis.

In comparison, the role of fickle international capital flows in a currency crisis as a trigger or a contributing factor has been well established both

\footnotetext{
${ }^{1}$ See Kim and Wei (2001) for a recent study of the possibility of momentum trading and herding by international investors in emerging markets.

${ }^{2}$ See, for example, Forbes and Rigobon (1999) for an argument on why the common definition of contagion may be inadequate.

${ }^{3}$ The standard deviations of the external loan-to-GDP and FDI-to-GDP ratios, averaged over 85 emerging economies, were 0.046 and 0.012 , respectively. The coefficients of variations for them were 2.19 and 1.27 , respectively. See Table 1 later for more details.

${ }^{4}$ For surveys of the literature on corruption and economic development, see Bardhan (1997), Kaufmann (1997), and Wei (1999). More recent papers on corruption include Wei (2000c) and Bai and Wei (2000). None of the surveys covers any empirical study that links crony capitalism with currency crisis.
} 
theoretically and empirically in the academic literature. The so-called 'secondgeneration currency crisis models' emphasize multiple equilibria - the possibility that with no or a small change in the fundamentals of an emerging economy, a massive change in international capital flows can occur that would precipitate a currency crisis; see, for example, Obstfeld (1994). Recognizing the difference in volatility among different types of capital flows, a large empirical literature on currency crisis has confirmed that the composition of capital inflows is related to a country's likelihood to run into a future currency crisis; see, for example, Frankel and Rose (1996), Radelet and Sachs (1998) and Rodrik and Velasco (1999). In particular, three types of composition measures have been highlighted in the literature as being particularly relevant for the discussion of currency crises: the lower the share of foreign direct investment in total capital inflows, the higher the short-term debt-toreserves ratio, or the higher the share of foreign currency denominated borrowing in a country's total borrowing, the more likely a currency crisis becomes.

By and large, crony capitalism and fickle international capital have been proposed as rival explanations of the crises in emerging economies. The aim of this article is to make a case that there may be an intimate connection between the two: a country with a severe problem of crony capitalism is more likely to have a distorted structure of capital inflows that makes the country vulnerable to a sudden reversal in international capital flows.

More concretely, the article presents evidence that corrupt countries have difficulty in attracting relatively stable foreign direct investment (FDI), and therefore are likely to rely more on relatively volatile international bank loans. ${ }^{5}$ A small (unfavourable) change in the recipient countries' fundamentals may cause a larger swing in the bank loans (e.g. from massive inflows to massive outflows) than FDI. This can strain the recipient country's currency or financial system sufficiently to cause or exacerbate its collapse (Radelet and Sachs 1998; Reisen 1999; Rodrik and Velasco 1999). ${ }^{6}$

Before explaining in more detail the connection between domestic crony capitalism and the structure of a country's capital inflows, let us first consider some counter-arguments. As a start, not everyone agrees that FDI is less volatile than international bank loans. For example, Dooley et al. (1995), and,

\footnotetext{
${ }^{5}$ On evidence on the other measures of the structure of capital flows (term structure of the bank loans, portfolio-to-GDP ratio, and the inability to borrow in a country's own currency from the international capital market), readers are referred to Wei and $\mathrm{Wu}$ (2001a).

${ }^{6}$ Of course, the composition of capital flows impacts economic development in ways that go beyond its effect on the propensity for a currency crisis. Indeed, many would argue that attracting FDI as opposed to international bank loans or portfolio investment is a more useful way to transfer technology and managerial know-how.
} 
more recently, Hausmann and Fernandez-Arias (2000) argue that FDI can be as volatile as, or even more volatile than, international bank loans (or portfolio flows). This is a matter of observable patterns in the data. In the next section, a comparison is made of the various types of capital flows (FDI, bank loans and portfolio capital) in terms of their volatility. The calculations are based on data for all 103 countries for which reliable data can be collected from 1980 to 1996, as well as for the subset of 85 emerging economies over the same period. The volatility is computed in two ways:

- As standard deviations of FDI-to-GDP, international bank loans-toGDP, and portfolio capital inflow-to-GDP ratios, respectively

- As coefficient of variations (standard deviations divided by the respective sample means) for the same three ratios.

The evidence suggests that, no matter which definition of volatility one uses, by and large, FDI is reliably less volatile than international bank loans.

The second possible counter-argument is that corruption could tilt the composition of capital inflows in an opposite direction from what is hypothesized above. Corruption is bad for both international direct investors and creditors. Corrupt borrowing countries are more likely to default on bank loans, or to nationalize (or otherwise diminish the value of) the assets of foreign direct investors. When this happens, there is a limit on how much international arbitration or court proceedings can help to recover the assets, as there is a limit on how much collateral the foreign creditors or direct investors can seize as compensation. ${ }^{7}$

There are reasons to think that international banks can be hurt by local corruption more than international direct investors can. Explicit insurance against political risk is available for purchase by direct investors through the World Bank's Multilateral Investment Guarantee Agency (MIGA). But such explicit insurance is not available for purchase by international banks. Indeed, the prolonged developing-country debt crisis in the 1980s suggests that international creditors could lose a substantial amount of money. Furthermore, international direct investors may have an informational advantage over international portfolio investors (and presumably banks). International direct investors could obtain more information about the local market by having managers from the headquarters stationed in the country in which they invest. As a consequence, the existence of cross-border informational asymmetry may lead to a bias in favour of international direct investment.

\footnotetext{
${ }^{7}$ In the old days, major international creditors and direct investors might rely on their navies to invade defaulting countries to seize more collateral. Such is no longer a (ready) option today.
} 
This is the logic underlying Razin et al.'s theory of (1998) of 'pecking order of international capital flows'.

These counter-arguments all seem reasonable. What are the reasons for arguing that corruption may tilt the composition of capital inflows to a higher bank loan-to-FDI ratio? There are essentially two.

First, the need for international investors to pay bribery and to deal with extortion by corrupt bureaucrats tends to increase with the frequency and the extent of their interactions with local bureaucrats. Given that international direct investors are more likely to have repeated interactions with local officials (for permits, taxes, health inspections, and so forth) than international banks or portfolio investors, local corruption would be more detrimental to FDI than other forms of capital flows. Along the same line, direct investment involves a greater sunk cost than bank loans or portfolio investment. Once an investment is made, when corrupt local officials start to demand bribery (in exchange for not setting up obstacles), direct investors would be in a weaker bargaining position than international banks or portfolio investors. This ex post disadvantage of FDI would make international direct investors more cautious ex ante in a corrupt host country than international portfolio investors. ${ }^{8}$

In the modern theory of corporate finance, there is a literature that argues that the risk of expropriation by the manager of a firm would induce the person who provides the external finance to the firm to prefer a debt contract as opposed to a direct equity participation (Townsend 1978; Gale and Hellwig 1985). This is so because debt contract requires less costly verification of how the manager uses the funds by the financier. One can think of an analogy for international capital flows. Crony capitalism enhances the possibility that the international capital may be expropriated in the capitalrecipient country and raises the cost for international investors to inspect its actual use. As a consequence, international investors may favour a debt contract (including bank loans) rather than an equity participation (including FDI).

There is a second reason why international direct investment is deterred more by local corruption than international bank credit or portfolio investment. The current international financial architecture is such that international creditors are more likely to be bailed out than international direct investors. For example, during the Mexican (and subsequent Tequila) crisis and the more recent Asian currency crisis, the IMF, the World Bank and the G7 countries mobilized a large amount of funds for these countries to

\footnotetext{
${ }^{8}$ Tornell (1990) presented a model in which a combination of sunk cost in real investment and uncertainty leads to under-investment in real projects even when the inflow of financial capital is abundant.
} 
minimize the potentially massive defaults on bank loans. So an international bailout of the bank loans in the event of a massive crisis has by now been firmly implanted in market expectations (even though a bailout may not be complete or certain). In addition, many developing-country governments implicitly or explicitly guarantee the loans borrowed by the private sector in the country. ${ }^{9}$ In comparison, there have been no comparable examples of international assistance packages for the recovery of nationalized or extorted assets of foreign direct investors. The insurance against political risk provided by the MIGA is insignificant in quantity and often expensive to acquire. This difference further tilts the composition of capital flows and makes banks more willing than direct investors to do business with corrupt countries.

Both reasons suggest the possibility that corruption may affect the composition of capital inflows in such a way that the country is more likely to experience a currency crisis. Ultimately, whether domestic corruption raises or lowers the ratio of external bank borrowing versus FDI is an empirical question. For illustration, consider some concrete examples from New Zealand, Singapore, Uruguay and Thailand. On the one hand, New Zealand and Singapore are two countries with low corruption (the exact source is explained in the next section). Their ratios of loan-to-FDI (0.11 and 0.44, respectively) and portfolio investment/FDI ( 0.07 and 0.09 , respectively) are relatively low. On the other hand, Uruguay and Thailand are two countries with high corruption. They have much higher ratios of loan-to-FDI (1.77 and 5.77, respectively) and of portfolio investment-to-FDI (1.40 and 1.76, respectively). So these examples are consistent with the notion that local corruption is correlated with patterns of capital inflows. Of course, these four countries are just examples. As such, there are two questions that need to be addressed more formally. First, does the association between corruption and composition of capital flows generalize beyond these four countries? Second, once we control for a number of other characteristics that affect the composition of capital inflows, would we still find the positive association between corruption and the loan/FDI ratio?

The rest of this paper is organized in the following way. In Section 2, some basics are laid out: the definition and measurement of crony capitalism, and a comparison of the difference in volatility of various types of international capital flows. In Section 3, statistical evidence is discussed on the relationship between domestic crony capitalism and the composition of capital inflows. Finally, in Section 4, concluding remarks are provided.

\footnotetext{
${ }^{9}$ McKinnon and Pill $(1996,2001)$ argue that the government guarantee generates 'moral hazard' which in turn leads the developing countries to 'overborrow' from the international credit market.
} 


\section{Some Basics}

\section{A. Crony Capitalism: How to Measure It?}

In this article, I treat 'crony capitalism' as synonymous to 'corruption involving government officials'. In a strict sense, these two terms are not the same. Corruption refers to the extent to which firms (or private citizens) need to pay bribes to government officials in their interactions (for permits, licenses, loans, and so forth). Crony capitalism, on the other hand, refers to an economic environment in which relatives and friends of government officials are placed in positions of power and government decisions on allocation of resources and judicial judgement on commercial disputes are distorted to favour these friends and relatives. In reality, the difference may be minor: crony capitalism almost always implies a widespread corruption as private firms and citizens in such an environment would find compelled to pay bribes to government officials in order to achieve anything.

The exact boundary of corruption or crony capitalism may depend on culture. What is called corruption in one country may not be so labelled in another. For example, a survey in mid-1990s in Thailand reveals that Thai people seem to tolerate certain behaviour by governmental officials as 'permissible' that would have been labelled as 'corruption' in the USA or Western Europe. However, this 'grey' area is probably not big. Severe abuses of power by government officials are regarded as corruption in all countries. It is these severe abuses that have the most important economic consequences that this article studies. The same Thai survey reveals that, despite some difference in the definition of corruption, most Thai people regarded corruption as a serious problem in their government, and wished something could be done about it. ${ }^{10}$

To implement empirical analysis, one has to have a way to measure the degree of 'crony capitalism'. By its very nature (of secrecy and illegality), the level of crony capitalism or corruption is difficult to quantify. There are three types of measures of corruption available, and all are perception-based subjective indexes. The first is a rating given by consulting firms' in-house consultants or 'experts'. Representative indexes are produced by the Business International (BI, now part of the Economist's Economic Intelligence Unit), and by Political Risk Services (which call its product 'International Country Risk Group' or ICRG rating). The second type is based on survey of business executives (or other people in the country in question). The rating for a

\footnotetext{
${ }^{10}$ The Thai survey is described in Pasuk and Piriyarangsan (1994).
} 
country is typically the average of the respondent's ratings. Examples of this include indexes in the Global Competitiveness Report (GCR) and World Development Report (WDR), which will be explained in more detail shortly. The third type is based on an average of existing indexes. The best-known example is the index produced by Transparency International (TI), a Germany-based non-governmental organization devoted to fighting corruption. A drawback of this type of index is that mixing indexes with different country coverage and methodologies could potentially introduce more noise to the measure.

Overall, corruption ratings based on surveys of firms are preferable to those based on the intuition of in-house experts. First, the executives who respond to the GCR or WDR surveys presumably have more direct experience with the corruption problem than the consultants who each typically have to rate many countries. Second, to the extent each individual respondent has idiosyncratic errors in his/her judgement, the averaging process in the WDR or WCR indexes can minimize the influence of such errors. In this paper, we use the indexes from the GCR and WDR surveys as our basic measure of corruption.

The GCR Index is derived from the Global Competitiveness Report 1997, produced jointly by the Geneva-based World Economic Forum and Harvard Institute for International Development. The survey for the report was conducted in late 1996 on 2,827 firms in 58 countries. The GCR Survey asked respondents (in Question 8.03) to rate the level of corruption in their country on a one-to-seven scale, based on the extent of 'irregular, additional payments connected with imports and exports permits, business licenses, exchange controls, tax assessments, police protection or loan applications'. The GCR Corruption Index is based on the country average of the individual ratings.

The WDR Index is derived from a World Bank survey in 1996, of 3,866 firms in 73 countries, in preparation for its World Development Report 1997. Question 14 of that survey asks: 'Is it common for firms in my line of business to have to pay some irregular "additional" payments to get things done?' The respondents were asked to rate the level of corruption on a one-to-six scale. The WDR corruption index is based on the country average of the individual answers. For both corruption indexes, the original sources are such that a higher number implies lower corruption. To avoid awkwardness in interpretation, they are re-scaled in this paper so that a high number now implies high corruption.

Since each index covers only a (different) subset of countries for which we have data on FDI or other forms of capital flows, it may be desirable to form a composite corruption index that combines the two indexes. The two indexes are derived from surveys with similar methodologies and similar questions. 
The correlation between the two is 0.83 . We follow a simple three-step procedure to construct the composite index:

1 Use GCR as the benchmark.

2 Compute the average of the individual ratios of GCR to WDR for all countries that are available in both GCR and the WDR.

3 For those countries that are covered by WDR but not GCR (which are relatively rare), convert the WDR rating into the GCR scale by using the average ratio in step 2 .

Finally, while the article uses an index of corruption as a measure of the degree of 'crony capitalism', I believe that the index captures something broader than just bureaucratic corruption. It may be useful to think of corruption and crony capitalism more broadly as shorthand for 'poor public governance', which can also include deviations from rule of law or excessive and arbitrary government regulations. All the existing empirical indicators on different dimensions of public governance are highly correlated; I do not think that we can separately identify their effects at this stage.

\section{B. The Fickleness of Different International Flows}

It may be useful to have a quick glance at the data on international capital flows. The argument that capital flow composition does matter requires that different capital flows have a different level of volatility. For every member country of the IMF for which relevant data is available for 1980-96, the standard deviations of three ratios (portfolio capital inflow/GDP, borrowingfrom-banks/GDP, and inward FDI/GDP) are computed. ${ }^{11}$ The results are

\footnotetext{
${ }^{11}$ Hausmann and Fernandez-Arias (2000) argue that the classification of capital inflows into FDI and other forms may not be accurate, and that it is possible for a reversal of an inflow of FDI to take the form of an outflow of bank loans or portfolio flows. As a result, calculations of relative volatility of the different forms of capital flows are not meaningful. We hold a different view. The misclassification can come from two sources: random measurement errors and intentional mis-reporting by international investors. In the first instance, if capital flows are misclassified at the margin due to random errors, the labels on FDI and other forms of capital flows are still useful. In the second instance, foreign investors may intentionally mis-report types of capital flows. Since there is a cost associated with mis-reporting, there is a limit on the magnitude of the error of this type as well. In the empirical work to be presented later in the paper, the bilateral FDI data are based on FDI source country governments' survey of their firms. The bilateral bank lending data are based on international lending banks' reporting to their governments (which then forward them to the Bank for International Settlement). There are no obvious incentives for multinational firms or international banks to mis-report their true FDI or loan positions to their governments.
} 
summarized in Table 1. For all countries in the sample (103 countries in total), the median volatility of FDI/GDP ratio is substantially smaller (less than a third) than the median volatility of the loan/GDP ratio and somewhat smaller than that of portfolio flows-to-GDP ratio. For the non-OECD countries as a group, the FDI/GDP ratio is also much less volatile than the loan/GDP ratio, although its median volatility is higher than that of the portfolio flow/GDP ratio.

Table 1: Volatility of FDI/GDP, Bank Loan/GDP, and Portfolio Flow/GDP as Measured by Standard Deviation or Coefficient of Variation: 1980-96

\begin{tabular}{llll}
\hline & FDI/GDP & Loan/GDP & Portfolio/GDP \\
\hline $\begin{array}{l}\text { Standard deviations } \\
\text { Whole sample: } 103 \text { countries }\end{array}$ & & & \\
$\quad$ Mean & 0.012 & 0.041 & 0.014 \\
$\quad$ Median & 0.008 & 0.033 & 0.009 \\
Emerging markets: 85 countries & & & \\
$\quad$ Mean & 0.012 & 0.046 & 0.012 \\
$\quad$ Median & 0.008 & 0.035 & 0.004 \\
Coefficients of variations & & & \\
Whole sample: 103 countries & & & \\
$\quad$ Mean & 1.176 & 1.567 & 2.764 \\
$\quad$ Median & 0.947 & 1.204 & 1.702 \\
Emerging markets: 85 countries & & & \\
$\quad$ Mean & 1.269 & 2.192 & 0.813 \\
$\quad$ Median & 1.163 & 1.177 & 2.042 \\
Selected countries & & & \\
$\quad$ Indonesia & 0.820 & 0.717 & 1.722 \\
$\quad$ Korea & 0.591 & 2.039 & 1.338 \\
$\quad$ Malaysia & 0.490 & 4.397 & 3.544 \\
$\quad$ Mexico & 0.452 & 2.048 & 2.088 \\
$\quad$ Philippines & 0.921 & 0.956 & 1.979 \\
Thailand & 0.571 & 0.629 & 1.137 \\
\hline
\end{tabular}

Only countries that have at least eight non-missing observations during 1980-96 for all three variables and whose populations are greater than or equal to one million in 1995 are kept in the sample.

OECD countries (with membership up to 1980) include: Australia, Austria, Canada, Denmark, Finland, France, Ireland, Italy, Japan, Netherlands, New Zealand, Norway, Portugal, Spain, Sweden, Switzerland, United Kingdom, United States. Emerging markets refer to all countries not on the above list and with a GDP per capita in 1995 less than or equal to US\$15,000 (in 1995 US\$).

Sources: Total inward FDI flows, total bank loans, and total inward portfolio investments are from the IMF's Balance of Payment Statistics, various issues, GDP data are from the World Bank's GDF \& WDI Central Databases. 
Alternatively, we may look at the coefficient of variation (standard deviation divided by the mean) of these three ratios. These results are presented in the lower half of Table 1. Again, for the group of emerging market economies, FDI/GDP is still substantially less volatile than the loan/FDI ratio, although the difference is smaller according to this measure. On the other hand, FDI/GDP is less volatile than the portfolio/GDP ratio according to median in the group, but not according to the mean of the group.

The lower part of the same table also presents the volatility of the three ratios (coefficients of variations) for a number of individual countries that featured prominently in the recent currency crises. Each country shows a portfolio/GDP ratio that is at least twice and as much as eight times as volatile as the FDI/GDP ratio. For all of these countries bar one, the loan/GDP ratio is also more volatile than the FDI/GDP ratio. If the sample period is extended to include 1997-98, the differences in volatility would be even more pronounced (not reported). Therefore, the data is consistent with the hypothesis that FDI is less sentiment-driven and hence more stable as a source of foreign capital.

The summary information and the coefficients of pairwise correlation for the key variables in this paper are presented in Tables $2 \mathrm{a}-2 \mathrm{c}$.

Table 2a: Summary Statistics

\begin{tabular}{lrrrrr}
\hline Variable & Obs. & Mean & Std. Dev. & Min & Max \\
\hline Corruption: GCR/WDR combined & 99 & 3.62 & 1.19 & 1.3 & 5.5 \\
Corruption: Transparency International & 85 & 5.12 & 2.40 & 0 & 8.6 \\
Tax rate (Highest corporate income tax rate) & 56 & 32.39 & 6.86 & 0 & 42 \\
FDI incentives & 49 & 1.65 & 0.69 & 0 & 3 \\
FDI restrictions & 49 & 1.69 & 1.18 & 0 & 4 \\
Per capita GDP, 1994-96 & 154 & 5792 & 9222 & 104 & 43602 \\
Ln(Loan/FDI), bilateral 1994-96 & 288 & 1.53 & 2.21 & -8.06 & 8.75 \\
Ln(Loan/FDI), balance of payment, 1994-96 & 125 & 0.31 & 2.00 & -4.84 & 6.18 \\
Ln(Portfolio/FDI), balance of payment, 1994-96 & 89 & -0.66 & 1.98 & -5.28 & 5.77 \\
\hline
\end{tabular}

Table 2b: Correlation Matrix I

\begin{tabular}{|c|c|c|c|c|c|c|c|}
\hline & $\begin{array}{l}\text { GDP } \\
\text { per capita }\end{array}$ & $\mathrm{TI}$ & $\begin{array}{l}\text { Corruption } \\
\text { GCR }\end{array}$ & WDR & Tax rate & $\begin{array}{l}\text { FDI } \\
\text { incentives }\end{array}$ & $\begin{array}{l}\text { FDI } \\
\text { restrictions }\end{array}$ \\
\hline GDP per capita & 1 & & & & & & \\
\hline Corruption-TI & -0.83 & 1 & & & & & \\
\hline Corruption-GCR & -0.77 & 0.87 & 1 & & & & \\
\hline Corruption-WDR & -0.72 & 0.86 & 0.83 & 1 & & & \\
\hline Tax rate & -0.16 & 0.16 & 0.06 & 0.34 & 1 & & \\
\hline FDI incentives & -0.48 & 0.31 & 0.30 & 0.18 & 0.22 & 1 & \\
\hline FDI restrictions & -0.42 & 0.49 & 0.44 & 0.51 & 0.09 & 0.28 & 1 \\
\hline
\end{tabular}


Table 2c: Correlation Matrix II

\begin{tabular}{lccc}
\hline & Log distance & Linguistic tie & Exchange rate volatility \\
\hline Log distance & 1 & & \\
Linguistic tie & 0.10 & 1 & 1 \\
Exchange rate volatility & -0.01 & -0.12 & 12 \\
\hline
\end{tabular}

\section{Statistical Analyses}

The aim of the statistical work is to link a country's composition of capital inflows with a measure of its degree of crony capitalism. Because of a lack of variation in the degree of crony capitalism over time (say over a few years) for most countries, we have to focus on a cross-section study. To obtain a meaningful number of observations and to weed out noises in the data, we choose to focus on a panel of bilateral bank lending and bilateral FDI. The data on bilateral bank lending, reported by the Bank for International Settlement, covers outstanding loans (that is, stocks) from 13 lending countries to 83 borrowing countries. After excluding missing observations, there are altogether 793 country pairs. The data on bilateral direct investment, reported by the OECD, covers the end-of-year stock of FDI from 18 source countries to 59 host countries. Unfortunately, the two data sets have mismatched country pairs. When we construct the ratio of bilateral bank loans to bilateral FDI, we have up to 225 country pairs that are common to both data sets.

As far as I know, there are no comparable data sets on bilateral portfolio flows from the developed countries to emerging markets. I have obtained a bilateral portfolio flow data from the USA to a panel of foreign countries. The number of observations (39) is small. The statistical results on this data set will be noted briefly later.

An important question to decide on is whether one should look at the stocks or the flows of FDI and bank loans. My judgement is that the stock levels are the right ones to look at. To see this, consider the profit optimization problem of a multinational firm choosing the optimal allocation of direct investment in various locations in the world. Let $K(j)$ be the stock of investment the multinational firm intends to allocate to host country $j$. Let $t(j)$ be the rate of corporate income tax in host country $j, b(j)$ be the rate of bribery the firm has to pay per unit of output, and $r$ be the rental rate of capital. Let $f[K(j)]$ be the output of the firm in host country $j$. There are $N$ possible host countries that the firm can invest in. The firm chooses the 
level of $K(j)$ for $j=1,2, \ldots, N$, to maximize its total after-tax and afterbribery profit:

$$
\pi=\sum_{j=1}^{N}\{[1-t(j)-b(j)] f[K(j)]-r K(j)\}
$$

Note that as a simple way to indicate that tax and corruption are distortionary, we let $[1-t(j)-b(j)]$ pre-multiply output rather than profit. The optimal stock of FDI in country $j, K(j)$, would, of course, be related to both the rate of tax and that of corruption in the host country: $K=K[t(j), b(j)]$, where $\partial K / \partial t<0$ and $\partial K / \partial b<0 .{ }^{12}$

Even though the observed stock of FDI in year $t$ contains investment flows made in the past, the optimization problem described above implies that the current flow should be adjusted in such a way so that the current stock should best reflect the current economic and policy environment of the host countries. The existence of adjustment costs, not discussed above, would suggest that the adjustment of the stock might not be made instantaneously. I do not have a measure of this adjustment cost. To allow for time-to-adjust, and to minimize the influence of other idiosyncratic sources of year-to-year fluctuations in foreign investment, I will use the average of the FDI over three years as a measure of bilateral FDI.

An analogous logic (optimization by a bank over loans to multiple destination countries) suggests that the stock of outstanding loans is the right variable to consider. Similar to the construction of the FDI variable, a threeyear average of the bilateral outstanding bank loans will be employed.

To study the effect of corruption on the composition of capital inflows is equivalent to asking whether corruption may have a differential impact on different forms of capital flows. Therefore, before we study the ratio of bank loans to FDI, we take a preliminary look at how FDI and bank loans, separately, may be linked to local corruption. This affords an opportunity to utilize the data points that exist for either FDI or loans but not both. Let $\operatorname{FDI}(k, j)$ be the bilateral stock of foreign direct investment from source country $k$ to host country $j$. In our empirical work, we start with the following benchmark specification:

$$
\begin{gathered}
\log [\operatorname{FDI}(k, j)]=\sum_{i} \alpha(i) D(i)+\beta_{1} \operatorname{tax}(j)+\beta_{2} \operatorname{corruption}(j)+ \\
X(j) \delta+Z(k, j) \gamma+e(k, j)
\end{gathered}
$$

\footnotetext{
${ }^{12} \mathrm{~A}$ more sophisticated generalization includes endogenizing the level of corruption (and tax) such as those in Shleifer and Vishny (1993) or Kaufmann and Wei (1999). These generalizations are outside the scope of the current paper.
} 
where $D(i)$ is a source country dummy that takes the value of one if the source country is $i$ (that is if $k=i$ ), and zero otherwise; $X(j)$ is a vector of characteristics of host country $j$ other than its tax and corruption levels; $Z(k, j)$ is a vector of characteristics specific to the source-host country pairs; $e(k, j)$ is an i.i.d. error that follows a normal distribution; and $\alpha(i), \beta_{1,}, \beta_{2}, \delta$, and $\gamma$ are parameters to be estimated.

This is a quasi-fixed-effects regression in that source country dummies are included. They are meant to capture all characteristics of the source countries that may affect the size of their outward FDI, including their size and level of development. In addition, possible differences in the source countries' definition of FDI are controlled for by these fixed effects under the assumption that the FDI value for a particular country pair under one country's definitions is proportional to that under another's, except for an additive error that is not correlated with other regressors in the regression. We do not impose host country fixed effects, as doing so would eliminate the possibility of estimating all the interesting parameters including the effect of corruption. [However, we will later add host-country random effects to the regressions.]

Using the combined GRC/WDR rating as the measure of corruption, the regression is run and reported in the first column of Table 3. Most variables have the expected signs and are statistically significant. A rise in host country tax rate is associated with less inward FDI. Government incentives and the restrictions on FDI have a positive and a negative coefficient, respectively, consistent with our intuition. Most importantly, corruption has a negative and statistically significant effect on FDI.

In Column 2 of Table 3, a similar regression is performed on the subset of country pairs that are common to the FDI and bank loan data sets. The central result is the same: a more corrupt host country receives less FDI.

Note that in the regressions, we have standardized the corruption measure (by subtracting the mean and dividing it by the sample standard deviation) so that the point estimate can be interpreted as the response of the left-hand-side variable with respect to a one-standard-deviation increase in corruption. Therefore, using the GCR/WDR measure of corruption (the first two columns of Table 3), a one-standard-deviation increase in corruption is associated with a $25-34 \%$ decline in FDI. In other words, the negative effect of corruption is not just statistically significant, it is quantitatively large. This finding is qualitatively in line with Wei (2000a), which employed a different econometric specification. See also Hines (1995), Wei (1997, 2000b, 2000d) and Smarzynska and Wei (2000) on empirical evidence that corruption deters FDI.

Similarly to the FDI regressions, one can examine the relationship between corruption and bilateral bank loans (except that government policies towards 
Table 3: Corruption, FDI and Bank Loans

\begin{tabular}{|c|c|c|c|c|}
\hline & \multicolumn{2}{|l|}{ FDI } & \multicolumn{2}{|l|}{ Loan } \\
\hline & $\begin{array}{l}\text { Whole } \\
\text { sample }\end{array}$ & $\begin{array}{l}\text { Common to } \\
\text { OCED/BIS } \\
\text { sources }\end{array}$ & $\begin{array}{l}\text { Whole } \\
\text { sample }\end{array}$ & $\begin{array}{l}\text { Common to } \\
\text { OCED/BIS } \\
\text { sources }\end{array}$ \\
\hline Corruption (GCR/WDR) & $\begin{array}{c}-0.337^{\star \star} \\
(0.100)\end{array}$ & $\begin{array}{c}-0.254^{*} \\
(0.149)\end{array}$ & $\begin{array}{l}0.278^{\star *} \\
(0.086)\end{array}$ & $\begin{array}{l}0.227^{\star *} \\
(0.095)\end{array}$ \\
\hline Tax rate & $\begin{array}{c}-0.026^{\star *} \\
(0.011)\end{array}$ & $\begin{array}{c}-0.024 \\
(0.019)\end{array}$ & & \\
\hline FDI incentives & $\begin{array}{l}0.324^{* *} \\
(0.094)\end{array}$ & $\begin{array}{l}0.381^{\star *} \\
(0.178)\end{array}$ & & \\
\hline FDI restrictions & $\begin{array}{c}-0.307^{\star *} \\
(0.057)\end{array}$ & $\begin{array}{c}-0.292^{\star *} \\
(0.101)\end{array}$ & & \\
\hline $\log (\mathrm{GDP})$ & $\begin{array}{l}0.830^{\star *} \\
(0.052)\end{array}$ & $\begin{array}{l}1.282^{\star *} \\
(0.126)\end{array}$ & $\begin{array}{l}0.957^{\star *} \\
(0.055)\end{array}$ & $\begin{array}{l}0.864^{\star *} \\
(0.095)\end{array}$ \\
\hline Log (per capita GDP) & $\begin{array}{c}-0.041 \\
(0.084)\end{array}$ & $\begin{array}{c}0.114 \\
(0.112)\end{array}$ & $\begin{array}{l}0.244^{\star *} \\
(0.064)\end{array}$ & $\begin{array}{l}0.174^{\star *} \\
(0.079)\end{array}$ \\
\hline Log distance & $\begin{array}{c}-0.539^{\star *} \\
(0.060)\end{array}$ & $\begin{array}{c}-0.563^{\star \star} \\
(0.108)\end{array}$ & $\begin{array}{c}-0.276^{* *} \\
(0.086)\end{array}$ & $\begin{array}{c}-0.253^{\star *} \\
(0.091)\end{array}$ \\
\hline Linguistic tie & $\begin{array}{l}1.379^{* *} \\
(0.207)\end{array}$ & $\begin{array}{l}0.859^{* *} \\
(0.347)\end{array}$ & $\begin{array}{l}0.593^{* *} \\
(0.197)\end{array}$ & $\begin{array}{c}0.001 \\
(0.230)\end{array}$ \\
\hline Exchange rate volatility & $\begin{array}{l}-5.943^{* *} \\
(1.421)\end{array}$ & $\begin{array}{c}-7.003^{* *} \\
(1.711)\end{array}$ & $\begin{array}{c}-11.802^{\star *} \\
(3.937)\end{array}$ & $\begin{array}{c}-7.663^{\star} \\
(4.593)\end{array}$ \\
\hline Inflation & & & $\begin{array}{c}0.0001 \\
(0.0002)\end{array}$ & $\begin{array}{c}0.00004 \\
(0.0002)\end{array}$ \\
\hline GDP growth & & & $\begin{array}{l}3.709^{* *} \\
(1.634)\end{array}$ & $\begin{array}{c}3.522 \\
(2.527)\end{array}$ \\
\hline Export growth & & & $\begin{array}{c}-0.958 \\
(1.260)\end{array}$ & $\begin{array}{c}0.468 \\
(2.415)\end{array}$ \\
\hline Adjusted $\mathrm{R}^{2} /$ overall $\mathrm{R}^{2}$ & 0.76 & 0.71 & 0.78 & 0.81 \\
\hline No. of obs. & 628 & 225 & 361 & 208 \\
\hline
\end{tabular}

Notes: ${ }^{* \star},{ }^{\star}$ and \# indicate significant at the $5 \%, 10 \%$, and $15 \%$ levels, respectively. Standard errors are in parentheses. $\log Y(k, j)=$ source country dummies $+b X(k, j)+e(k, j)$; where $Y(k, j)$ is FDI or loan from source country $k$ to host country $j$. All regressions include source country dummies whose coefficients are not reported to save space. $\log (\mathrm{FDI}), \log (\mathrm{GDP})$ and $\log$ (per capita GDP) are averaged over 1994-96. Exchange rate volatility = standard deviation of the first difference in log monthly exchange rate (bilateral) over 1991:1-1993:12. Inflation is the average inflation rate over 1991-93. GDP growth is the average over 1991-93, calculated as [Log (GDP of 1993) - $\log$ (GDP of 1990)]/3. Export growth is the average over 1991-93, calculated as [Log (export of 1993) - $\log ($ export of 1990)]/3. 
FDI and tax rate on foreign-invested firms are omitted). ${ }^{13}$ The regression results are reported in the second half of Table 3. Somewhat surprisingly, the coefficient on corruption is positive and statistically significant. That is, corrupt countries on average obtain more loans from international banks. In regressions not reported here, I also restrict the sample to a single lending country (such as France, Japan and the United States). Generally speaking, the coefficient on corruption in the loan regression continues to be positive (though not always significant).

The earlier part of the paper suggests two stories in which international direct investors are more discouraged by local corruption than international banks. The first is that greater sunk costs or greater ex post vulnerability of the direct investment would make direct investors more cautious ex ante than international banks in doing business in a corrupt host country. The second is the greater probability of an implicit or explicit bailout provided by the current international financial system to international loans than international direct investment. These stories explain only a compositional shift away from FDI towards bank loans in corrupt recipient countries. Are they also consistent with an absolute increase in the borrowing from international banks by corrupt countries? One possibility is that FDI and international bank loans are imperfect substitutes. In a corrupt recipient country, precisely because of the lost FDI due to corruption, there are relatively more activities that need to be financed by borrowing from international banks. This conjecture remains to be confirmed by future research.

Putting the results on FDI and bank loans together, it would seem natural to expect that corruption would raise the ratio of bank loans to FDI. To verify that this is indeed the case, we also check directly the connection between the ratio of bank loans to FDI and host country corruption. We perform a fixedeffects regression of the following sort:

$$
\log \left(\operatorname{loan}_{k j} / \mathrm{FDI}_{k j}\right)=\text { source country fixed effects }+\beta \text { corruption }_{j}+X_{k j} \Gamma+e_{k j}
$$

The regression result is reported in the first column in Table 4. As expected, the coefficient on corruption is positive and statistically significant at the $5 \%$ level. Basing on the point estimate, we see that a one-standard-deviation increase in corruption is associated with roughly a 55\% increase in the loanto-FDI ratio (e.g. from $100 \%$ to $155 \%$ ).

\footnotetext{
${ }^{13} \mathrm{We}$ have not found a consistent data source on government policies towards international bank borrowing across countries, nor are we able to construct such a series from the $\mathrm{PwC}$ country reports.
} 
Table 4: Composition of Capital Flows - Dependent variable: $\log (\operatorname{loan})$ $\log (\mathrm{FDI})$, averaged over 1994-96

\begin{tabular}{|c|c|c|c|c|c|c|}
\hline & \multicolumn{2}{|c|}{ GCR/WDR } & \multicolumn{2}{|l|}{ TI } & \multirow{2}{*}{\multicolumn{2}{|c|}{$\begin{array}{l}\text { GCR/WDR } \\
\text { IV } \\
\text { Fixed effects }\end{array}$}} \\
\hline & $\begin{array}{l}\text { Fixed } \\
\text { effects }\end{array}$ & $\begin{array}{l}\text { Random } \\
\text { effects }\end{array}$ & $\begin{array}{l}\text { Fixed } \\
\text { effects }\end{array}$ & $\begin{array}{l}\text { Random } \\
\text { effects }\end{array}$ & & \\
\hline Corruption & $\begin{array}{c}0.544^{* *} \\
(0.126)\end{array}$ & $\begin{array}{l}0.548^{\star *} \\
(0.221)\end{array}$ & $\begin{array}{c}0.496^{\star *} \\
(0.167)\end{array}$ & $\begin{array}{c}0.477^{\star} \\
(0.278)\end{array}$ & $\begin{array}{c}0.296^{*} \\
(0.181)\end{array}$ & $\begin{array}{c}0.282 \# \\
(0.183)\end{array}$ \\
\hline Tax rate & $\begin{array}{c}0.013 \\
(0.017)\end{array}$ & $\begin{array}{c}0.015 \\
(0.031)\end{array}$ & $\begin{array}{c}0.010 \\
(0.017)\end{array}$ & $\begin{array}{c}0.011 \\
(0.029)\end{array}$ & & \\
\hline FDI incentives & $\begin{array}{c}0.324^{* \star} \\
(0.151)\end{array}$ & $\begin{array}{c}0.400 \# \\
(0.259)\end{array}$ & $\begin{array}{c}0.152 \\
(0.157)\end{array}$ & $\begin{array}{c}0.224 \\
(0.255)\end{array}$ & $\begin{array}{c}0.111 \\
(0.156)\end{array}$ & $\begin{array}{c}0.114 \\
(0.156)\end{array}$ \\
\hline FDI restrictions & $\begin{array}{l}0.374^{* *} \\
(0.085)\end{array}$ & $\begin{array}{l}0.342^{\star *} \\
(0.159)\end{array}$ & $\begin{array}{l}0.382^{\star *} \\
(0.087)\end{array}$ & $\begin{array}{l}0.337^{\star *} \\
(0.150)\end{array}$ & $\begin{array}{l}0.336^{\star *} \\
(0.093)\end{array}$ & $\begin{array}{l}0.311^{\star *} \\
(0.100)\end{array}$ \\
\hline $\log (\mathrm{GDP})$ & $\begin{array}{l}-0.491^{\star *} \\
(0.107)\end{array}$ & $\begin{array}{l}-0.529^{\star *} \\
(0.191)\end{array}$ & $\begin{array}{l}-0.500^{* *} \\
(0.111)\end{array}$ & $\begin{array}{l}-0.522^{\star *} \\
(0.183)\end{array}$ & $\begin{array}{l}-0.274^{\star *} \\
(0.115)\end{array}$ & $\begin{array}{l}-0.236^{*} \\
(0.127)\end{array}$ \\
\hline Log (per capita GDP) & $\begin{array}{c}0.150 \# \\
(0.095)\end{array}$ & $\begin{array}{c}0.184 \\
(0.177)\end{array}$ & $\begin{array}{c}0.190 \# \\
(0.119)\end{array}$ & $\begin{array}{c}0.208 \\
(0.204)\end{array}$ & $\begin{array}{c}0.034 \\
(0.103)\end{array}$ & $\begin{array}{c}0.018 \\
(0.105)\end{array}$ \\
\hline Log distance & $\begin{array}{c}0.355^{\star *} \\
(0.092)\end{array}$ & $\begin{array}{l}0.530^{\star *} \\
(0.113)\end{array}$ & $\begin{array}{c}0.355^{\star *} \\
(0.094)\end{array}$ & $\begin{array}{l}0.514^{* *} \\
(0.113)\end{array}$ & $\begin{array}{c}0.123 \\
(0.132)\end{array}$ & $\begin{array}{c}0.157 \\
(0.140)\end{array}$ \\
\hline Linguistic tie & $\begin{array}{c}-0.626^{\star *} \\
(0.295)\end{array}$ & $\begin{array}{c}-0.653^{\star *} \\
(0.283)\end{array}$ & $\begin{array}{c}-0.656^{\star *} \\
(0.304)\end{array}$ & $\begin{array}{c}-0.674^{\star \star} \\
(0.288)\end{array}$ & $\begin{array}{c}-0.753^{\star *} \\
(0.289)\end{array}$ & $\begin{array}{c}-0.769^{\star *} \\
(0.291)\end{array}$ \\
\hline Exchange rate volatility & $\begin{array}{c}4.293^{\star *} \\
(1.452)\end{array}$ & $\begin{array}{l}5.086^{\star \star} \\
(2.460)\end{array}$ & $\begin{array}{c}4.638^{\star *} \\
(1.505)\end{array}$ & $\begin{array}{l}5.319^{\star *} \\
(2.391)\end{array}$ & & $\begin{array}{c}-3.457 \\
(4.800)\end{array}$ \\
\hline $\begin{array}{l}\text { Over-identifying restriction } \\
\text { (P-value of the test) }\end{array}$ & & & & & 0.43 & 0.53 \\
\hline Adjusted $\mathrm{R}^{2} /$ overall $\mathrm{R}^{2}$ & 0.55 & 0.54 & 0.53 & 0.52 & - & - \\
\hline No. of obs. & 225 & 225 & 225 & 225 & 180 & 180 \\
\hline
\end{tabular}

$\mathrm{TI}=$ Transparency International index; IV = instrumental variable. See also, notes to Table 3.

Based on this regression, Figure 1 presents a partial scatter plot of loan-toFDI ratio against corruption, controlling for several characteristics of the host countries as described in the regression. A visual inspection of the plot suggests that the positive association between corruption and capital composition is unlikely to go away if we omit any one or two observations. In other words, the positive association is not likely to be driven by outliers. Hence, the evidence suggests that a corrupt country tends to have a composition of capital inflows that is relatively light in FDI and relatively heavy in bank loans.

Also note that because FDI is more relationship-intensive (as proxied by physical and linguistic distances) than bank loans, the coefficients on geographic distance and the linguistic tie dummy are positive and negative, respectively. 


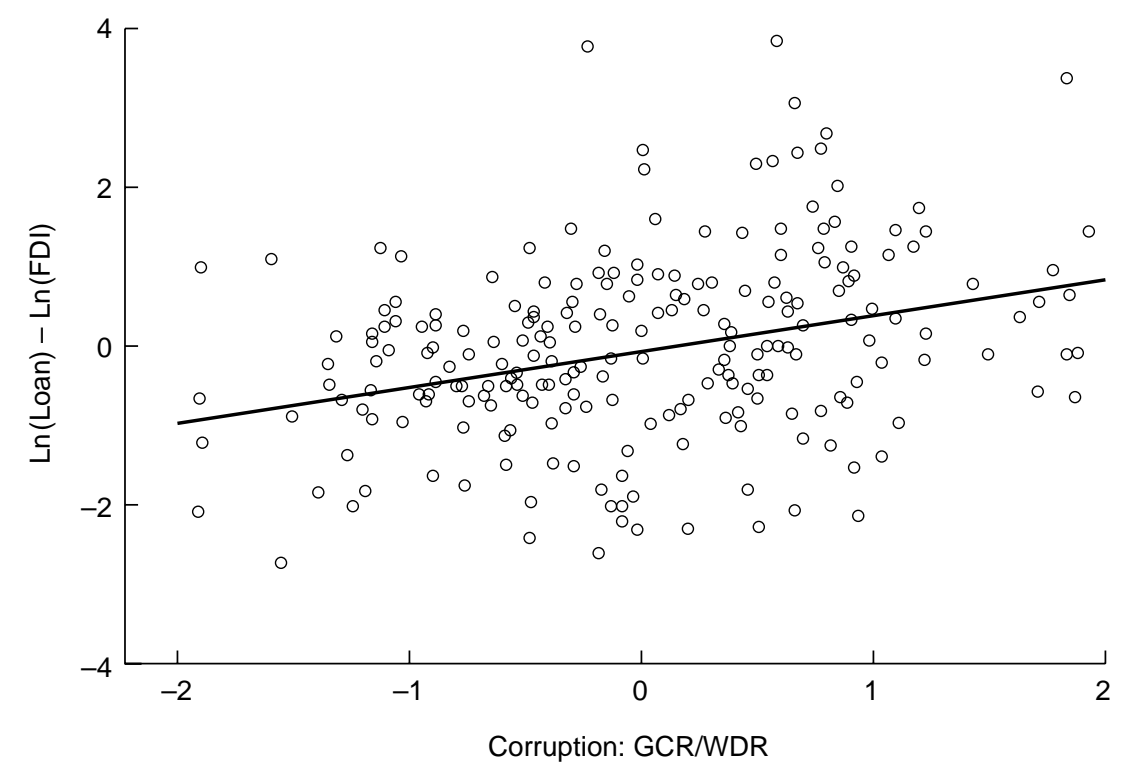

Figure 1: Composition of capital inflows and corruption

(Partial correlation based on Table 4, Column 1)

We may be concerned with correlation in the residual due to other hostcountry-specific influences. While we cannot address this issue completely by including host-country fixed effects, we can, however, include host-country random effects in the regression. The result is reported in the second column of Table 4. Although there are some changes in the size of the point estimates, the basic qualitative feature remains the same.

In Columns 3 and 4, a different measure of corruption - the Transparency International index - is employed. Again, where there are some changes in the point estimates, the central message stays the same: the level of corruption is positively associated with a country's relative dependence on the more volatile bank borrowing.

Finally, one might be concerned with possible endogeneity of the corruption measure. For example, survey respondents may perceive a country to be corrupt in part because they observe very little FDI going there. In this case, the positive association between the loan-to-FDI ratio and corruption can be due to a reverse causality.

In this subsection, we perform instrumental variable (IV) regressions on our key regressions. Mauro (1995) argued that ethnolinguistic fragmentation is a good IV for corruption. His ethnolinguistic indicator measures the probability that two persons from a country are from two distinct ethnic groups. The greater the indicator, the more fragmented the country. In 
addition, La Porta et al. (1998) argued that legal origin or colonial history has an important impact on the quality of government bureaucracy. These variables are used as instruments for the corruption measure. A first-stage regression suggests that ethnically more fragmented countries are more corrupt. In addition, countries with a French legal origin (which includes colonies of Spain and Portugal) are more corrupt than former British colonies.

The IV regressions are reported in the last two columns of Table 4. A test of over-identifying restrictions does not reject the null hypothesis that the instruments are uncorrelated with the error term. The results from these two IV regressions are still consistent with the notion that corruption deters FDI more than bank loans. Therefore, countries that are more corrupt tend to have a capital inflow structure that relies relatively more on bank borrowing than FDI.

In Table 5, the basic regressions are repeated with the addition of three new regressors: average inflation rate, GDP growth rate, and export growth rate of the capital-recipient countries. These are the additional regressors that have been employed in previous studies on international bank lending; see, for example, Dahl and Shrieves (1999). The results indicate that a higher inflation rate is associated with a lower loan-to-GDP ratio. The coefficient on GDP growth is not statistically different from zero. The negative coefficient on export growth probably results from the fact that faster export growth stimulates FDI more than bank lending. Since these variables are not grounded in a formal theory, the interpretation is a bit ambiguous. However, what is important for the objective of this paper is that, even after one accounts for a possible effect from these variables on the composition of capital inflows, there is a still a positive association between domestic crony capitalism and the external loan-to-FDI ratio.

The regression specification adopted here forces certain observations to be dropped. Whenever FDI or bank lending is zero, the regression procedure used so far would drop these observations. However, our left-hand-side variable, the ratio of bank loans to FDI, does not lend itself naturally to a Tobit specification. For this reason, the following transformation of the ratio is constructed as the left-hand-side variable: $\log ($ bank lending +0.1$)-\log ($ FDI +0.1$)$. With this new variable, there is a small increase in the number of observations (from 225 to 231). The regression results are not reported to save space, but the most important message is the same as before: corruption tilts the composition of capital inflows away from FDI and towards international bank loans.

While bilateral data on portfolio investment other than bank credits are not available for the whole set of capital-exporting countries examined in this article, we can obtain data on portfolio investment originating from the US (to a set of developing countries). Unfortunately, the number of observations is small (between 35 to 39 depending on the regression specification). So the 
Table 5: Composition of Capital Flows: Additional Regressors

\begin{tabular}{|c|c|c|c|c|}
\hline & \multicolumn{2}{|c|}{ GCR/WDR } & \multicolumn{2}{|l|}{ TI } \\
\hline & $\begin{array}{l}\text { Fixed } \\
\text { effects }\end{array}$ & $\begin{array}{l}\text { Random } \\
\text { effects }\end{array}$ & $\begin{array}{l}\text { Fixed } \\
\text { effects }\end{array}$ & $\begin{array}{l}\text { Random } \\
\text { effects }\end{array}$ \\
\hline Corruption & $\begin{array}{l}0.427^{* *} \\
(0.123)\end{array}$ & $\begin{array}{l}0.407^{\star *} \\
(0.191)\end{array}$ & $\begin{array}{c}0.393^{\star *} \\
(0.163)\end{array}$ & $\begin{array}{c}0.367 \# \\
(0.235)\end{array}$ \\
\hline Tax rate & $\begin{array}{c}0.025 \\
(0.017)\end{array}$ & $\begin{array}{c}0.021 \\
(0.028)\end{array}$ & $\begin{array}{c}0.021 \\
(0.018)\end{array}$ & $\begin{array}{c}0.017 \\
(0.026)\end{array}$ \\
\hline FDI incentives & $\begin{array}{c}0.160 \\
(0.162)\end{array}$ & $\begin{array}{c}0.220 \\
(0.242)\end{array}$ & $\begin{array}{c}0.038 \\
(0.166)\end{array}$ & $\begin{array}{c}0.087 \\
(0.230)\end{array}$ \\
\hline FDI restrictions & $\begin{array}{l}0.531^{\star \star} \\
(0.095)\end{array}$ & $\begin{array}{l}0.518^{\star \star} \\
(0.154)\end{array}$ & $\begin{array}{l}0.536^{\star *} \\
(0.097)\end{array}$ & $\begin{array}{c}0.528^{\star \star} \\
(0.143)\end{array}$ \\
\hline $\log (\mathrm{GDP})$ & $\begin{array}{c}-0.336^{\star *} \\
(0.115)\end{array}$ & $\begin{array}{c}-0.365^{\star *} \\
(0.183)\end{array}$ & $\begin{array}{c}-0.331^{\star *} \\
(0.118)\end{array}$ & $\begin{array}{c}-0.347^{\star \star} \\
(0.172)\end{array}$ \\
\hline Log (per capita GDP) & $\begin{array}{c}0.090 \\
(0.094)\end{array}$ & $\begin{array}{c}0.112 \\
(0.151)\end{array}$ & $\begin{array}{c}0.134 \\
(0.120)\end{array}$ & $\begin{array}{c}0.143 \\
(0.176)\end{array}$ \\
\hline Log distance & $\begin{array}{l}0.350^{\star *} \\
(0.116)\end{array}$ & $\begin{array}{l}0.465^{\star *} \\
(0.132)\end{array}$ & $\begin{array}{l}0.330^{\star *} \\
(0.118)\end{array}$ & $\begin{array}{l}0.436^{* *} \\
(0.130)\end{array}$ \\
\hline Linguistic tie & $\begin{array}{c}-0.575^{\star *} \\
(0.284)\end{array}$ & $\begin{array}{c}-0.668^{\star *} \\
(0.278)\end{array}$ & $\begin{array}{l}-0.616^{\star *} \\
(0.289)\end{array}$ & $\begin{array}{c}-0.681^{\star *} \\
(0.281)\end{array}$ \\
\hline Exchange rate volatility & $\begin{array}{c}2.055 \\
(2.532)\end{array}$ & $\begin{array}{c}2.978 \\
(3.813)\end{array}$ & $\begin{array}{c}3.108 \\
(2.565)\end{array}$ & $\begin{array}{c}3.578 \\
(3.576)\end{array}$ \\
\hline Inflation & $\begin{array}{c}-0.001^{\star *} \\
(0.0002)\end{array}$ & $\begin{array}{c}0.0005^{\star} \\
(0.0002)\end{array}$ & $\begin{array}{c}-0.001^{\star *} \\
(0.0002)\end{array}$ & $\begin{array}{c}-0.001^{\star *} \\
(0.0002)\end{array}$ \\
\hline GDP growth & $\begin{array}{c}5.676 \# \\
(3.647)\end{array}$ & $\begin{array}{c}4.237 \\
(5.749)\end{array}$ & $\begin{array}{c}4.226 \\
(3.778)\end{array}$ & $\begin{array}{c}3.401 \\
(5.446)\end{array}$ \\
\hline Export growth & $\begin{array}{c}-8.373^{* *} \\
(3.596)\end{array}$ & $\begin{array}{c}-7.536 \\
(5.631)\end{array}$ & $\begin{array}{c}-7.397^{\star} \\
(3.768)\end{array}$ & $\begin{array}{c}-7.258 \\
(5.404)\end{array}$ \\
\hline (P-value of the test) & & & & \\
\hline Adjusted $\mathrm{R}^{2} /$ overall $\mathrm{R}^{2}$ & 0.60 & 0.59 & 0.58 & 0.58 \\
\hline No. of obs. & 208 & 208 & 208 & 208 \\
\hline
\end{tabular}

See the notes to Tables 3 and 4 .

power of the statistical tests is likely to be low. Several fixed-effects regressions are performed in a way analogous to Table 4 (not reported). We see again that, at least for this sub-sample, the portfolio-investment-to-FDI ratio is also positively related to the capital-importing country's corruption level. The more corrupt a country, the less FDI it receives (relative to portfolio capital). However, when we use the TI corruption index, the coefficients on corruption are no longer statistically significant although they are always positive. The insignificance can be consistent with a genuinely zero coefficient or can result from a low power of the test due to the small sample size.

Additional regressions are performed on the maturity structure of bank loans, and on the ability of a country to borrow in its own currency. Briefly, 
there is no robust correlation between a country's corruption level and the share of short-term borrowing (with terms less than and up to one year) in its total bank borrowing. However, there is some weak evidence for a positive association between a country's corruption level and its inability to borrow in its own currency from the international capital market (measured by the ratio of borrowing in foreign currencies, such as the US dollar, and its total foreign borrowing). These results are not reported to save space.

\section{Conclusion}

Crony capitalism affects the composition of capital inflows in a way that is not favourable to the country. A corrupt country receives substantially less FDI. However, it may not be as much disadvantaged in obtaining bank loans. Indeed, international bank loans appear to be stimulated by local corruption, possibly to pick up the investment opportunities shunned by international direct investors. As a result, corruption in a capital-importing country tends to tilt the composition of its capital inflows away from FDI and towards foreign bank loans. This result is robust across different measures of corruption and different econometric specifications.

There are two possible reasons for this effect. First, FDI are more likely to be expropriated by local corrupt officials ex post than foreign loans. As a result, less FDI would go to corrupt countries ex ante. Second, the current 'international financial architecture' is such that there is more insurance/ protection from the IMF and the G7 governments for bank lenders from developed countries than for direct investors.

Previous research - starting with Frankel and Rose (1996) - has shown that a capital inflow structure that is relatively low in FDI is associated with a greater propensity for a future currency crisis. It may be that international bank loans (or other portfolio flows) swing more than direct investment in the event of bad news (real, or self-generated by international investors) about economic or policy fundamentals. If so, this paper has provided evidence for one possible channel through which corruption in a developing country may increase its chances of running into a future crisis.

In the literature on the causes of currency crises, crony capitalism and selffulfilling expectations by international creditors are often proposed as two rival hypotheses. Indeed, authors that subscribe to one view often do not accept the other. The evidence in this paper suggests a natural linkage between the two. Crony capitalism, through its effect on the composition of a country's capital inflows, makes it more vulnerable to the self-fulfilling expectationstype of currency crisis. 
Corruption could also weaken domestic financial supervision and produce a deteriorated quality of banks' and firms' balance sheets. This would be an additional channel for corruption to raise the likelihood of a currency/ financial crisis. The evidence on this awaits future research.

Shang-Jin Wei

New Century Chair in International Economics and Senior Fellow

Brookings Institution

1775 Massachusetts Avenue, N.W.

Washington, DC 20036, USA

swei@brook.edu

\section{Appendix A: Country Coverage in the Sample}

For bilateral FDI, the source countries were Australia, Austria, Canada, Finland, France, Germany, Iceland, Italy, Japan, Korea, Netherlands, New Zealand, Norway, Poland, Sweden, Switzerland, United Kingdom, and the United States. The host countries were Algeria, Argentina, Australia, Austria, Belgium-Luxembourg, Brazil, Bulgaria, Canada, Chile, China, Colombia, Costa Rica, Czech Republic, Denmark, Egypt, Finland, France, Germany, Greece, Hong Kong, Hungary, Iceland, India, Indonesia, Iran, Ireland, Israel, Italy, Japan, Korea, Kuwait, Libya, Malaysia, Mexico, Morocco, Netherlands, New Zealand, Norway, Panama, Philippines, Poland, Portugal, Romania, Russian Federation, Saudi Arabia, Singapore, Slovak Republic, Slovenia, South Africa, Spain, Sweden, Switzerland, Taiwan, Thailand, Turkey, Ukraine, United Arab Emirates, United Kingdom, United States and Venezuela.

For bilateral international bank loans, the lending countries were Austria, Belgium, Canada, Finland, France, Germany, Italy, Japan, Luxembourg, Netherlands, Spain, United Kingdom and the United States. The borrowing countries were Albania, Argentina, Armenia, Australia, Azerbaijan, Belarus, Benin, Bolivia, Brazil, Bulgaria, Cameroon, Chad, Chile, China, Colombia, Congo Republic, Costa Rica, Cote d'Ivoire, Czech Republic, Ecuador, Egypt, Arab Republic, El Salvador, Estonia, Fiji, Georgia, Ghana, Greece, Guatemala, Guinea, Guinea-Bissau, Honduras, Hungary, Iceland, India, Indonesia, Islamic Republic, Israel, Jamaica, Jordan, Kazakhstan, Kenya, Korea Republic, Kyrgyz Republic, Latvia, Lithuania, Madagascar, Malawi, Malaysia, Mali, Mauritius, Mexico, Moldova, Morocco, Mozambique, Namibia, New Zealand, Nicaragua, Niger, Nigeria, Pakistan, Paraguay, Peru, Philippines, Poland, Portugal, Romania, Russian Federation, Senegal, Slovak Republic, South Africa, Taiwan, Tanzania, Thailand, Tonga, Tunisia, Turkey, Uganda, Ukraine, Uruguay, Uzbekistan, Venezuela, Vietnam, Zambia and Zimbabwe.

(C) Blackwell Publishers Ltd. 2001 


\section{Appendix B: Source and Construction of the Variables}

For bilateral bank loans, the source was the Bank for International Settlements. Data are at the end of December in millions of US\$. Loans to offshore banking centers are omitted.

For bilateral FDI, the sources were the OECD, International Direct Investment Statistics Yearbook 1999, Diskettes. Units used: millions of US\$ (converted into US\$ using the yearly average exchange rates from annex III of the book).

Distance: The greater circle distance (in $\mathrm{km}$ ) between economic centres (usually capital cities) in a pair of countries based on the latitude and longitude data. Source for latitude and longitude: Rudloff (1981), updated from Pearce and Smith (1984).

Linguistic tie: Source of major languages: CIA world facts book, from http://www.odci.gov/cia/publications/factbook/

Dummy $=1$ if the two countries share a common language or have a former colonial relation.

Corruption-GCR Index: Source is Global Competitiveness Report 1997. Transformation: values in this paper $=8-$ original values.

Corruption-WDR Index: Original source is World Development Report 1997. Data are from Kaufmann and Wei (1999). Transformation: values in this paper $=8-$ original values.

Corruption-TI Index: Source: Transparency International (http://www. gwdg.de/ uwvw/icr.htm) 1998 index. Transformation: values in this paper $=10-$ the original values. Thus, a bigger number means more corruption.

Gross domestic product (GDP) and GDP per capita: Source is the World Bank SIMA/GDF \& WDR central database. GDP data are at market prices (constant 1995 US\$).

Monthly exchange rate (end of period): Source is IMF, International Financial Statistics, via the World Bank SIMA databases.

Legal origins: Source: La Porta et al. (1998).

Corporate tax rates: Source: PricewaterhouseCoopers (2000), with supplementary information World Economic Forum (1998).

\section{Appendix C: Statistics}

Table 6 gives the standard deviation and coefficient of variation of FDI/GDP, loan GDP and portfolio/GDP by countries. 


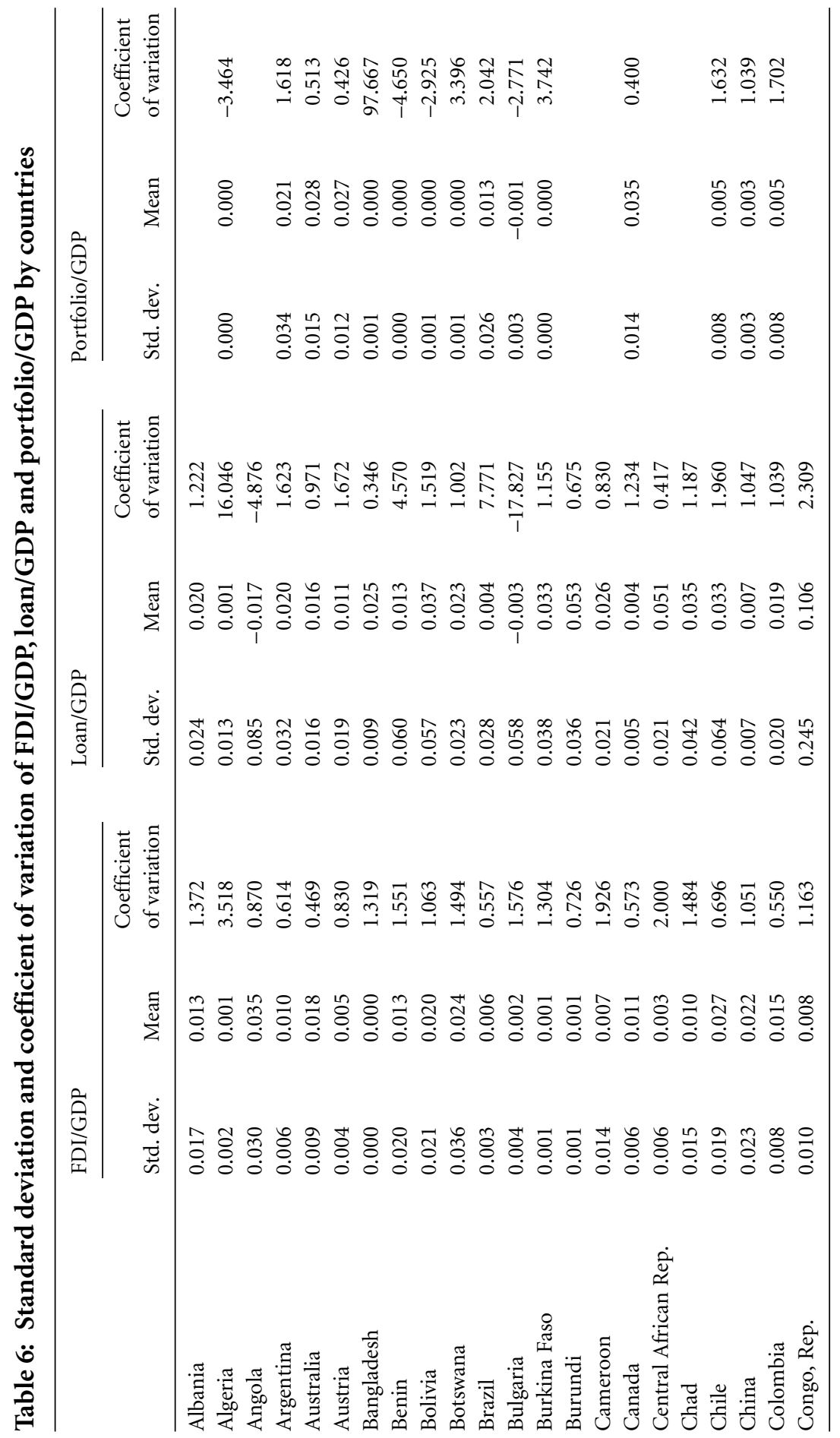




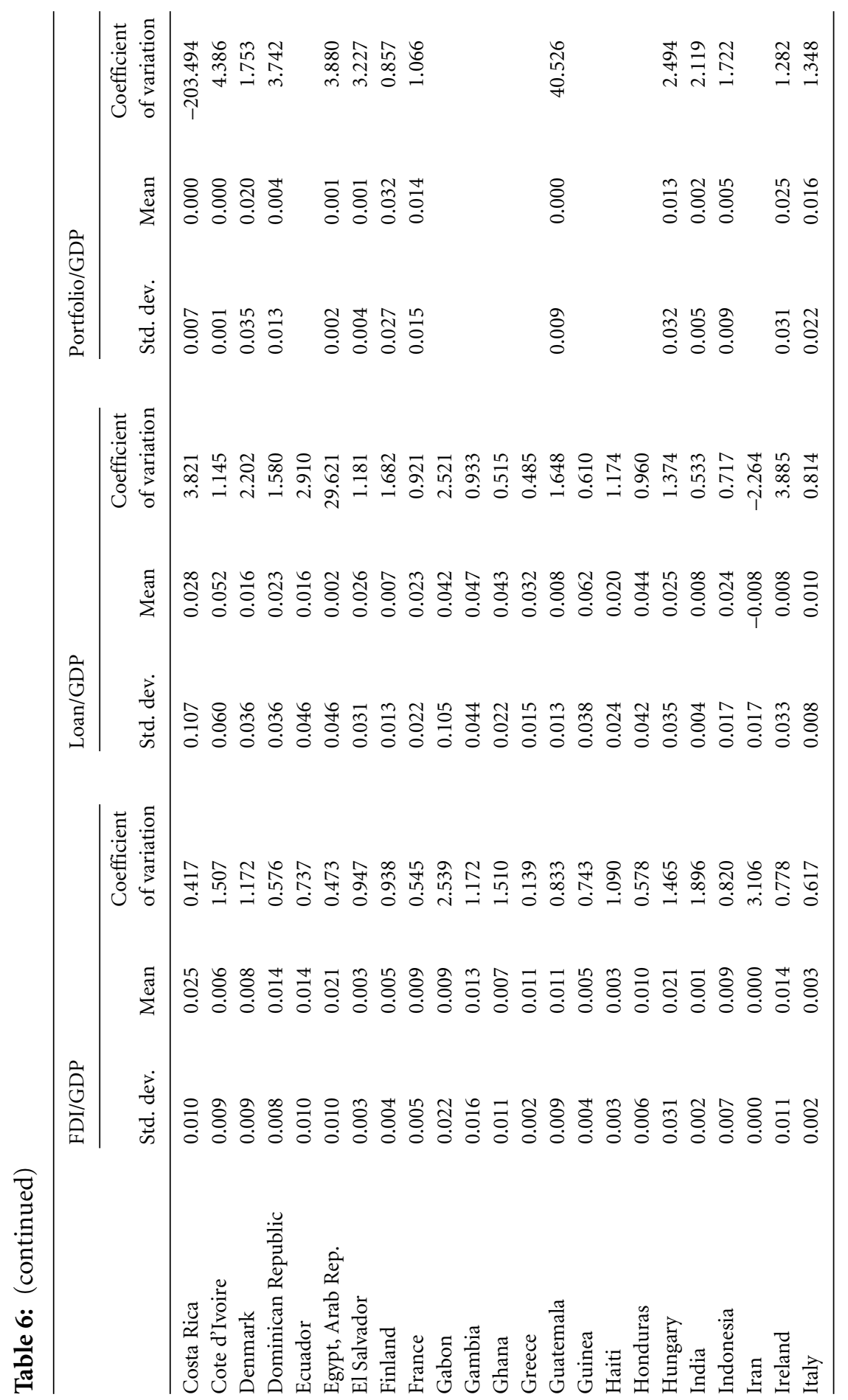




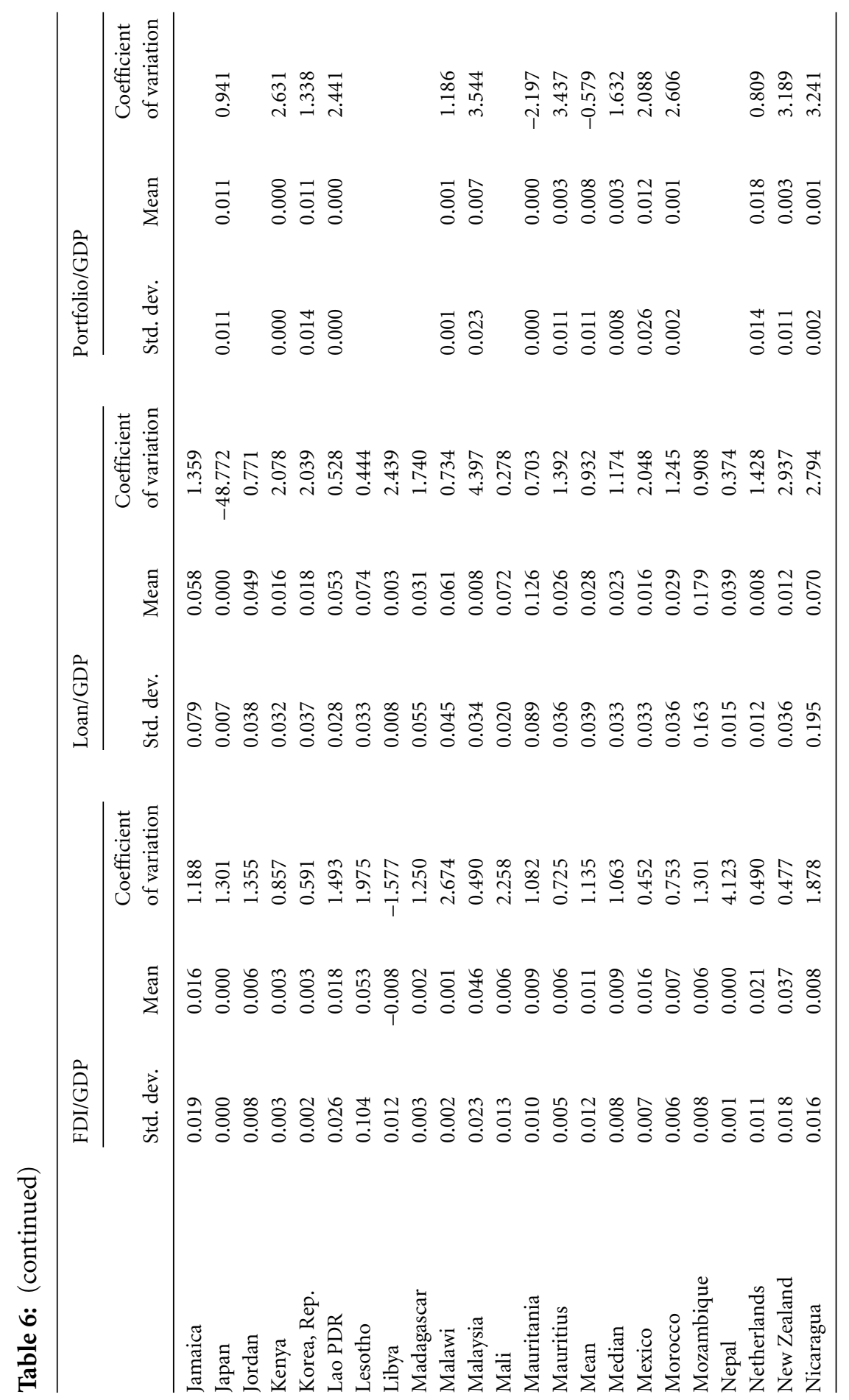




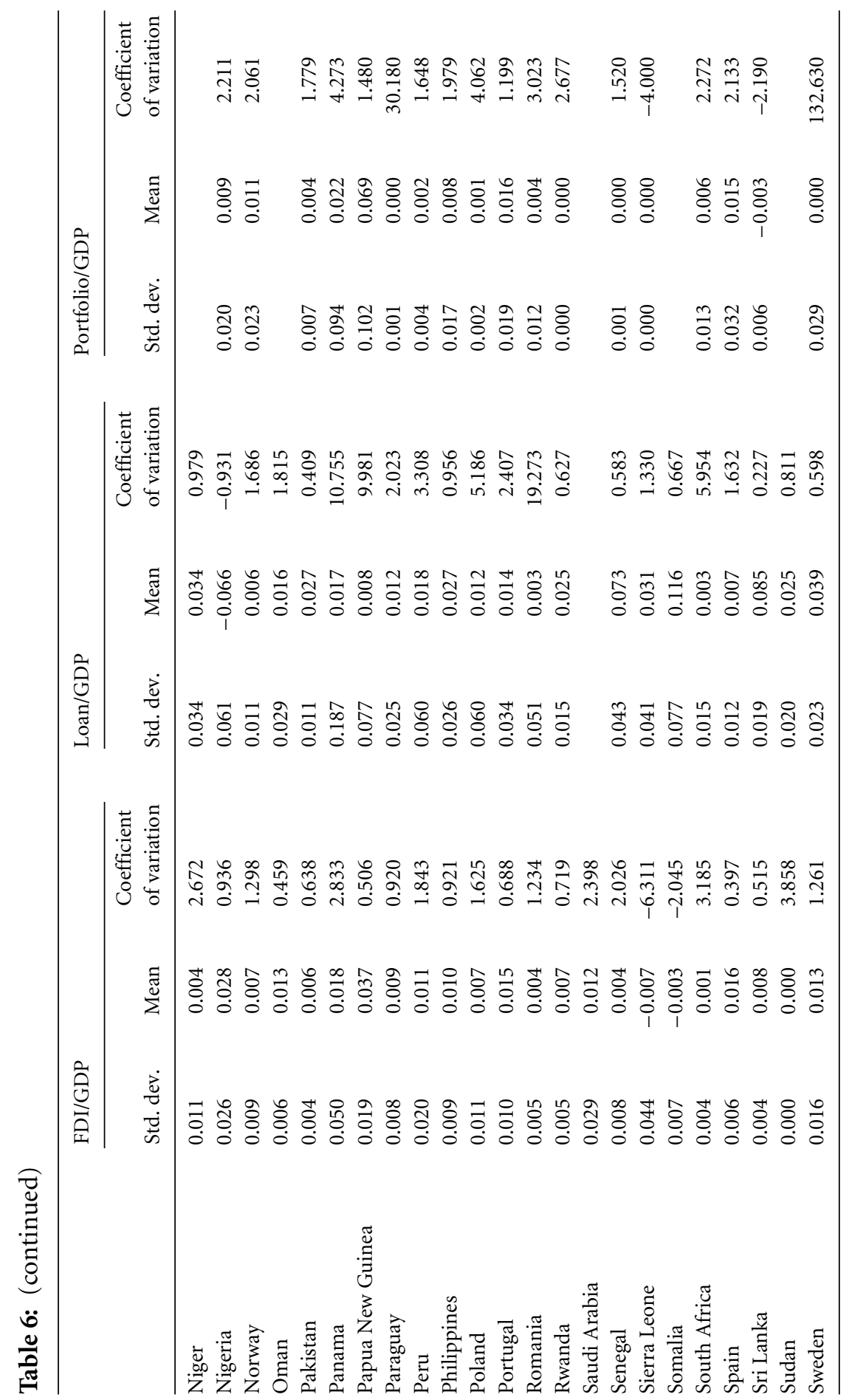




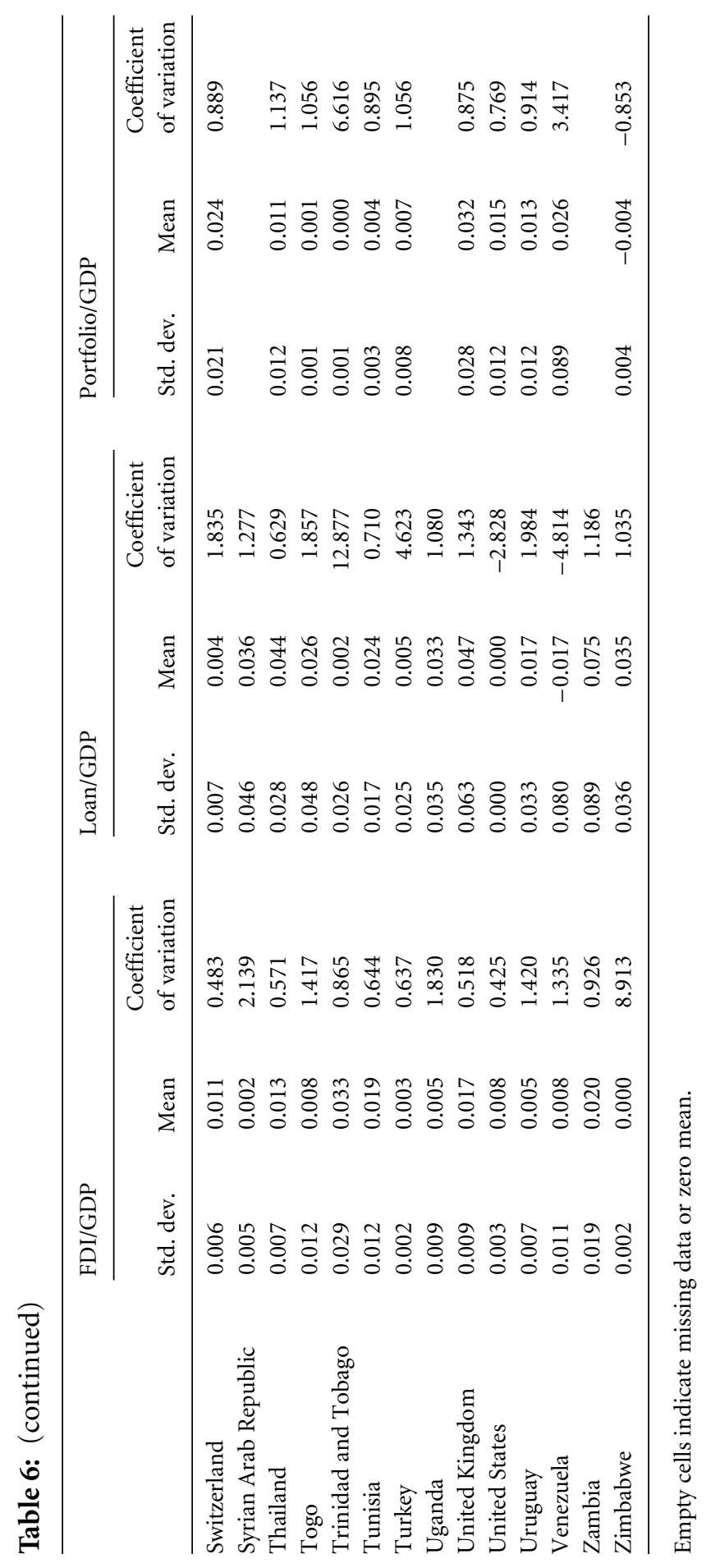




\section{References}

Bai, Chong-En, and Shang-Jin Wei (2000), 'Quality of Bureaucracy and OpenEconomy Macro Policies', NBER Working Paper No. 7766, June.

Bardhan, Pranab (1997), 'Corruption and Development: A Review of Issues', Journal of Economic Literature, 35, September, 1320-46.

Dahl, D., and R. E. Shrieves (1999), 'The Extension of International Credit by US Banks: A Disaggregated Analysis, 1988-1994', Journal of International Money and Finance, 18, 153-67.

Dooley, M. P., S. Classens and A. Warner (1995), 'Portfolio Capital Flows: Hot or Cool?', World Bank Economic Review, 9(1), 53-174. Reprinted in Mike J. Howell, ed., 1996, Investing in Emerging Markets. London, UK: Eurocurrency Publications.

Forbes, Kristin, and Roberto Rigobon (1999), 'Interdependence, Not Contagion', NBER Working Paper No. 7267.

Frankel, J. A., and A. K. Rose (1996), 'Currency Crashes in Emerging Markets: An Empirical Treatment', Journal of International Economics, 41(3-4), November, 351-66.

Gale, D., and M. Hellwig (1985), 'Incentive-compatible Debt Contracts: The OnePeriod Problem', Review of Economic Studies, 52, 647-63.

Hausmann, Ricardo, and Eduardo Fernandez-Arias (2000), 'Foreign Direct Investment: Good Cholesterol?', Inter-American Development Bank Working Paper No. 417, March 26.

Hines, James (1995), 'Forbidden Payment: Foreign Bribery and American Business After 1977', NBER Working Paper No. 5266, September.

International Monetary Fund, Balance of Payments Statistics, various issues.

Johnson, Simon, Peter Boone, Alasdair Breach and Eric Friedman (2000), 'Corporate Governance in the Asian Financial Crisis', Journal of Financial Economics, 58(1-2), $141-86$.

Kaufmann, Daniel (1997), 'Corruption: Some Myths and Facts', Foreign Policy, Summer, 114-31.

Kaufmann, Daniel, and Shang-Jin Wei (1999), 'Does “Grease Payment” Speed Up the Wheels of Commerce?', National Bureau of Economic Research Working Paper No. 7093.

Kim, Woochan, and Shang-Jin Wei (2001), 'Foreign Portfolio Investors Before and During a Crisis', Journal of International Economics, forthcoming.

La Porta, Rafael, Florencio Lopez-de-Silanes, Andrei Shleifer and Robert Vishny (1998), 'Law and Finance', Journal of Political Economy, 106, 1113-55.

Mauro, Paolo (1995), 'Corruption and Growth', Quarterly Journal of Economics, 110, 681-712.

McKinnon, Ronald, and Huw Pill (1996), 'Credible Liberalization and International Capital Flows: The Overborrowing Syndrome’, in Ito Takatoshi and Anne O. Krueger, 
eds, Financial Deregulation and Integration in East Asia. Chicago: University of Chicago Press, 7-45.

- (2001), 'Exchange Rate Regimes for Emerging Markets: Moral Hazard and International Overborrowing', Oxford Review of Economic Policy, forthcoming. Stanford University and Harvard University.

Obstfeld, Maurice (1994), 'The Logic of Currency Crises', Cahiers de Economiques et Monetaires, Banque de France. No. 43, 189-213.

OECD (1999), International Direct Investment Statistics Yearbook. Paris: OECD Publication. [There is an associated data diskette.]

Pasuk, Phongpaichit, and Sungsidh Piriyarangsan (1994), Corruption and Democracy in Thailand. Chiang Mai: Silkworm Books, Thailand.

Pearce, E. A., and C. G. Smith (1984), The World Weather Guide. London: Hutchinson.

PricewaterhouseCoopers (2000), 'Doing Business and Investing Worldwide', (on CD-ROM).

Radelet, Steven, and Jeffrey Sachs (1998), 'The East Asian Financial Crisis: Diagnosis, Remedies, and Prospects', Brookings Papers on Economic Activities, 1, 1-74.

Razin, Assaf, Efraim Sadka and Chi-Wa Yuen (1998), 'A Pecking Order of Capital Inflows and International Tax Principles', Journal of International Economics, 44, 45-68.

Reisen, Helmut (1999), 'The Great Asian Slump', OECD Development Centre.

Rodrik, Dani, and Andres Velasco (1999), 'Short-Term Capital Flows', paper prepared for the 1999 World Bank Annual Bank Conference on Development Economics. Harvard University and New York University.

Rudloff, Willy (1981), World Climates, with Tables of Climatic Data and Practical Suggestions. Stuttgart: Wissenschaftliche Verlagsgesellschaft.

Shleifer, Andrei, and Robert Vishny (1993), 'Corruption,' Quarterly Journal of Economics, 108, 599-617.

Smarzynska, Beata, and Shang-Jin Wei (2000), 'Corruption and the Composition of Foreign Direct Investment: Firm-level Evidence', The National Bureau of Economic Research Working Paper No. 7969.

Tornell, Aaron (1990), 'Real vs. Financial Investment: Can Tobin Taxes Eliminate the Irreversibility Distortion?', Journal of Development Economics, 32, 419-44.

Townsend, Robert (1978), 'Optimal Contracts and Competitive Markets with Costly State Verification', Journal of Economic Theory, 21, 265-93.

Wei, Shang-Jin (1997), 'Why is Corruption So Much More Taxing Than Taxes? Arbitrariness Kills', NBER Working Paper No. 6255, November.

- (1999), 'Corruption in Economic Development: Beneficial Grease, Minor Annoyance, or Major Obstacle?', The World Bank Policy Research Working Paper No. 2048, February.

- (2000a), 'How Taxing is Corruption on International Investors?', Review of Economics and Statistics, 82(1), February, 1-11. 
— (2000b), 'Why Does China Attract So Little Foreign Direct Investment?', in Ito Takatoshi and Anne O. Krueger, eds, The Role of Foreign Direct Investment in East Asian Economic Development. Chicago and London: University of Chicago Press, 239-61.

(2000c), 'Local Corruption and Global Capital Flows', Brookings Papers on Economic Activity, 2.

(2000d), 'Natural Openness and Good Government', NBER Working Paper No. 7765, June.

Wei, Shang-Jin, and Yi Wu (2001a), 'Negative Alchemy? Corruption, Composition of Capital Flows, and Currency Crises', NBER working paper No. 8187, March. Forthcoming in Sebastian Edwards and Jeffrey Frankel, eds, Preventing Currency Crises. Chicago: University of Chicago Press.

(2001b), 'Is Crony Capitalism a Source of Exchange Rate Instability?', unpublished working paper.

World Economic Forum (1998), The Global Competitiveness Report 1998. Geneva, Switzerland: World Economic Forum. 